\title{
The human heat shock protein hsp70 interacts with HSF, the transcription factor that regulates heat shock gene expression
}

\author{
Klara Abravaya, Michael P. Myers, Shawn P. Murphy, and Richard I. Morimoto ${ }^{1}$ \\ Department of Biochemistry, Molecular Biology and Cell Biology, Northwestern University, Evanston, Illinois 60208 USA
}

\begin{abstract}
Transcriptional regulation of the human $h s p 70$ gene in response to heat shock and other forms of physiological stress occurs through the activation of heat shock transcription factor (HSF). Exposure of cells to a heat shock temperature of $42^{\circ} \mathrm{C}$ results in transient activation of HSF; its DNA-binding activity increases rapidly, plateaus, and attenuates, during which the intracellular levels of hsp70 increase. In an effort to understand whether HSF is regulated negatively by hsp70, we have examined whether HSF associates with hsp70. We show that activated HSF associates with hsp70 and that the interaction is detected as the levels of hsp70 increase in the cell. Addition of ATP and other hydrolyzable nucleotides results in the dissociation of hsp70 from HSF while nonhydrolyzable nucleotide analogs do not disrupt the complex. We demonstrate that exogenous recombinant wild-type hsp70 can associate with activated HSF, whereas no association is observed with an amino-terminal or a carboxy-terminal deletion mutant of hsp70. We also show that hsp70 blocks the in vitro activation of HSF from its cryptic non-DNA-binding state to a DNA-binding form; this inhibitory effect of hsp70 is abolished by ATP. We suggest that hsp70 may negatively regulate the activation of HSF.
\end{abstract}

[Key Words: Heat shock protein; human hsp70 gene; heat shock transcription factor]

Received February 26, 1992; revised version accepted April 20, 1992.

The analysis of inducible gene expression has provided many insights into the molecular mechanisms of transcriptional control. Activation of heat shock genes in response to elevated temperature and other environmental stresses has been studied extensively as a paradigm for inducible gene expression. These studies have revealed that induction of heat shock genes in higher eukaryotes is mediated by the activation of a preexisting heat shock factor (HSF), which binds to a target sequence, the heat shock element (HSE), located in the promoters of heat-induced genes (Pelham 1982; Amin et al. 1988; Xiao and Lis 1988; for review, see Morimoto et al. 1990; Wu et al. 1990; Sorger 1991). In higher eukaryotes, the activation of HSF involves its conversion from a cryptic non-DNA-binding form to a sequence-specific DNA-binding form (for review, see Wu et al. 1990). Recent studies revealed that this conversion is accompanied by oligomerization of the factor (Westwood et al. 1991).

In human HeLa and K562 cells, the activation of HSF and subsequent induction of heat shock genes occurs only during the initial phase of a $42^{\circ} \mathrm{C}$ heat shock, following which deactivation of $\mathrm{HSF}$ and attenuation of

${ }^{1}$ Corresponding author. heat shock gene transcription is observed (Mosser et al. 1988; Abravaya et al. 1991b; L. Sistonen, K. Sarger, B. Phillips, K. Abravaya, and R. Morimoto, in prep.). Our previous studies have revealed a tight correlation between heat shock gene transcription rates, heat-induced HSE-binding activity as measured by in vitro binding assays, and in vivo occupancy of the HSE on the HSP70 promoter as analyzed by genomic footprinting experiments (Abravaya et al. 1991a,b; L. Sistonen, K. Sarge, B. Phillips, K. Abravaya, and R. Morimoto, in prep.). The mechanism of attenuation is not well understood in higher eukaryotes, yet represents an important step in the regulation of the heat shock response. Experiments in Drosophila suggested a homeostatic mechanism where hsp70 autoregulates the response (DiDomenico et al. 1982; Solomon et al. 1991). The mechanism of autoregulation has been further investigated in Escherichia coli and yeast. In E. coli, the transcriptional induction of heat shock genes is mediated by an alternate $\sigma$-factor, $\sigma^{32}$ (Grossman et al. 1984, 1987; Straus et al. 1987). The synthesis and stability of $\sigma^{32}$ is negatively regulated by heat shock proteins, resulting in the shutoff of the heat shock response (Straus et al. 1989, 1990; Tilly et al. 1989 |. In both $E$. coli and yeast, mutations in hsp70 result in overexpression of heat shock genes (Tilly et al. 1983; Craig and Jakobsen 1984; Straus et al. 1989; for 
review, see Craig and Gross 1991). One study in yeast revealed that this phenotype was dependent on the HSE, thus implying that HSF is a target in autoregulation (Boorstein and Craig 1990). However a direct demonstration of negative regulation of HSF activity by hsp70 remained to be demonstrated.

hsp70 belongs to a family of related proteins, the 70$\mathrm{kD}$ heat shock proteins. The $70-\mathrm{kD}$ heat shock proteins are known to interact with other proteins and maintain or alter their conformational states (for review, see Morimoto et al. 1990; Pelham 1990; Gething and Sambrook 1992). They have been shown to participate in protein folding, translocation of proteins across membranes, assembly of monomeric proteins to larger macromolecular complexes, and disassembly of protein aggregates (for review, see Pelham 1990). Among proteins that are known to interact with the $70-\mathrm{kD}$ heat shock proteins are a number of cellular and viral proteins such as SV40 large $\mathrm{T}$ antigen, polyoma virus middle $\mathrm{T}$ antigen, mutant forms of the cellular oncoprotein $\mathrm{p} 53$, and the progesterone receptor (Pinhasi-Kimsi et al. 1986; Hinds et al. 1987; Walter et al. 1987; Clarke et al. 1988; Kost et al. 1989; Pallas et al. 1989; Sawai and Butel 1989). The functional significance of these associations remains to be established. The 70-kD heat shock proteins bind to ATP and have a weak ATPase activity (Zylicz et al. 1983; Welch and Feramisco 1985). Release of 70-kD heat shock proteins from their substrates is dependent on ATP hydrolysis (Pelham 1986; Clarke et al. 1988; Flynn et al. 1989; Kost et al. 1989; Beckmann et al. 1990; Palleros et al. 1991). Among the heat shock proteins, $70-\mathrm{kD}$ proteins are not unique in their participation in protein-protein interactions; hsp90 interacts with the glucocorticoid hormone receptor and the pp $60^{s r c}$ oncoprotein /Catelli et al. 1985; Sanchez et al. 1985; Brugge 1986; Picard et al. 1990|. These proteins are not functionally active when complexed with hsp90.

The ability of heat shock proteins to interact with other proteins and, in some instances, to block their activity, prompted us to determine whether hsp70 associates with HSF and whether hsp 70 modulates the activity of HSF. In this study we provide evidence that hsp70 associates with activated HSF and that this interaction is disrupted by ATP and other hydrolyzable nucleotides. The formation of this complex correlates with the level of hsp70 in the cell and can be reconstituted by addition of exogenous recombinant hsp70. To address whether hsp70 interferes with activation of HSF, we have taken advantage of an in vitro activation protocol in which HSF is converted from its non-DNA-binding form to a DNA-binding state. We show that addition of exogenous hsp70 completely inhibits the in vitro activation of HSF and that inhibition is relieved by ATP.

\section{Results}

In vivo-activated HSF associates with hsp 70

To determine whether hsp70 associates with HSF, gel mobility-shift assays were performed with an oligonu-

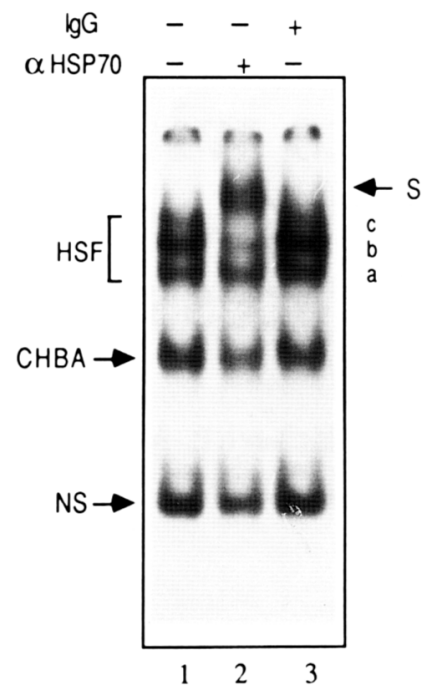

Figure 1. HSF associates with hsp70. Cell extracts from K562 cells heat-shocked for $3 \mathrm{hr}$ were preincubated with anti-hsp70 antibody, C92 (lane 2), or with goat anti-mouse IgG (lane 3). Antibody was not added to the sample in lane 1. Complexes due to nonspecific (NS) DNA-binding proteins, constitutive HSEbinding activity (CHBA), and HSF are marked. HSF-HSE complex consists of three bands: $(a, b$, and $c)$. (S) The slower migrating, supershifted complex.

cleotide containing the HSE sequence from the human hsp70 promoter (Mosser et al. 1988) and whole-cell extracts from human K562 cells that were preincubated with the anti-hsp 70 monoclonal antibody C92 (Welch and Mizzen 1988). The addition of anti-hsp70 antibody to extracts from cells heat-shocked for $3 \mathrm{hr}$ resulted in the appearance of a supershifted complex while the addition of equivalent amounts of anti-mouse IgG had no effect on the mobility of the HSF-HSE complex (Fig. 1). This result suggests that in cells heat-shocked for $3 \mathrm{hr}$, some of the activated HSF is complexed with hsp 70 . Other DNA-binding activities present in the extract, such as the nonspecific and the constitutive HSE-binding activity (CHBA), present in non-heat-shocked cells and distinct from HSF (Mosser et al. 1988; Abravaya et al. 1991a), were not affected by the anti-hsp70 antibody (Fig. 1). The HSF-HSE complex consists of multiple bands, referred to as $a, b$, and $c$. The addition of antihsp70 antibody, which results in the appearance of the supershifted complex, also results in the loss of the c band and a decrease in the intensity of the b band, whereas the a band is not affected (Fig. 1). These observations led us to suggest that hsp70 is a component of the c complex and, to a lesser extent, of the b complex.

To determine whether the ability of the anti-hsp70 antibody to supershift was specific to HSF-HSE complexes, anti-hsp70 antibody was examined for its effect on the mobilities of other transcription factor-DNA complexes. The electrophoretic mobilities of complexes bound to oligonucleotides containing CCAAT-, Sp1-, and ATF-binding sites were unaffected by anti-hsp70 antibody (data not shown). 


\section{ATP disrupts hsp70-HSF complexes}

A characteristic feature of $70-\mathrm{kD}$ heat shock protein interactions with protein substrates is the disruption of the complex by the addition of ATP (Pelham 1986; Clarke et al. 1988; Flynn et al. 1989; Kost et al. 1989; Beckmann et al. 1990, Palleros et al. 1991). To examine whether the addition of exogenous ATP would cause the release of hsp70 from HSF, we compared the HSF-HSE complexes formed in the absence or presence of exogenous ATP. The addition of ATP resulted in a dramatic change in the representation of the $a, b$, and $c$ bands characteristic of the HSF-HSE complexes (Fig. 2). In the presence of high concentrations of ATP $/ \mathrm{Mg}^{2+}$ (10 mM each), both the $b$ and $\mathrm{c}$ bands were diminished while the a band became prominent (Fig. 2, lane 2). Addition of lower concentrations of ATP $(0.1 \mathrm{mM})$ had the same effect on the a and c bands while the $b$ band was unaffected (data not shown). Addition of anti-hsp70 antibody to extracts treated with ATP did not result in a supershifted complex (Fig. 2, cf. lanes 3 and 4). These results suggest that addition of ATP results in the disruption of the HSF-hsp70 complexes.

The lack of a supershifted complex in the presence of anti-hsp70 antibody and ATP could also be the result of an ATP-dependent conformational change in hsp70 that would abolish its recognition by the antibody. To examine this possibility, immunoprecipitations were performed in the presence or absence of ATP using the antihsp70 antibody and extracts from ${ }^{35} \mathrm{~S}$-labeled cells. The addition of ATP to the extracts had no effect on the ability of anti-hsp70 antibody to immunoprecipitate hsp70 (data not shown). This result thus eliminates the possibility that ATP binding alters the epitope recognized by the anti-hsp70 antibody. Therefore, we suggest that ATP disrupts the HSF-hsp70 interaction and that the a band represents the hsp 70 "free" form of HSF while hsp 70 is a component of the slower migrating complexes. It is possible that these slower migrating complexes that are disrupted upon addition of ATP contain other heat shock proteins as well. The exact composition of these complexes remains to be determined.

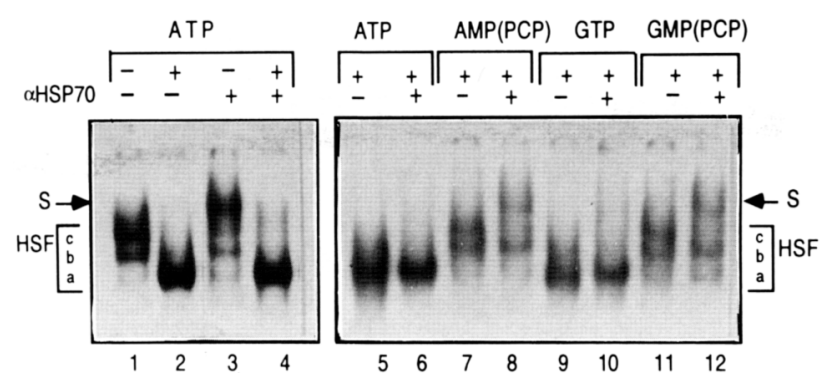

Figure 2. ATP disrupts the HSF/hsp70 complex. Whole-cell extracts from HeLa cells heat-shocked for $60 \mathrm{~min}$ were preincubated with ATP (lanes 2,4,5,6), AMP(PCP) (lanes 7,8), GTP (lanes 9,10), and GMP(PCP) (lanes 11,12), in the presence of $\mathrm{Mg}^{2+}$. Anti-hsp70 antibody was added to samples indicated. The three bands $(a, b, c)$ that constitute the HSF shift are indicated, and the supershift is marked S. Only the $a$ band is observed in the presence of ATP and GTP.
Although numerous studies on $70-\mathrm{kD}$ heat shock proteins have demonstrated that ATP is the optimal cofactor, $70-\mathrm{kD}$ heat shock protein-substrate complexes have been shown to be disrupted by other nucleotides (Sawai and Butel 1989|. Therefore, several nucleotides were tested for their ability to disrupt the HSF-hsp70 complex. As shown in Figure 2, GTP (lanes 9,10) was as effective as ATP (lanes 5 and 6) in releasing hsp70 from HSF. The nucleotides CTP, UTP, and dATP also released hsp70 from HSF (data not shown). The effect of nucleotides was tested at several concentrations (0.01-100 $\mathrm{mM}$ ), and at a given concentration no difference was observed among these nucleotides (data not shown). However, addition of the nonhydrolyzable analogs AMP(PCP) (lanes 7,8 ) and GMP(PCP) (lanes 11,12) did not cause disruption of the hsp70-HSF complex, suggesting that hydrolysis is necessary for release.

\section{HSF-hsp70 association correlates with the level of hsp70 in the cell}

To determine whether the formation of the HSF-hsp70 complex was correlated with intracellular levels of hsp70, extracts from cells heat-shocked for $10 \mathrm{~min}$ and 3 hr were compared in the presence of anti-hsp70 antibodies (Fig. 3A). While the addition of anti-hsp70 to extracts from cells heat-shocked for $3 \mathrm{hr}$ resulted in the appearance of the supershifted complex as observed previously, the presence of anti-hsp70 antibodies did not alter the migration of HSF-HSE complex when extracts from cells heat-shocked for 10 min were used (Fig. 3A). As shown by Western blot analysis (Fig. 3B), hsp70 levels increase approximately threefold in $\mathrm{K} 562$ cells heat-shocked for 3 hr, whereas a 10 -min heat shock has no effect on the level of hsp70. This observation suggested that formation of the supershifted complex may be driven by high levels of hsp70. We extended this observation using 293 cells, a human embryonic kidney cell line, which constitutively express high levels of hsp70 (Fig. 3B) owing to the activation of the $h s p 70$ gene by the adenovirus E1A protein (Kao and Nevins 1983; Wu et al. 1986; Williams et al. 1989). When whole-cell extracts from 10-min heatshocked 293 cells were preincubated with anti-hsp 70 antibody and analyzed by gel mobility-shift assay, the majority of the HSE-HSF complex was supershifted (Fig. $3 \mathrm{~A}$, lanes 7,8 ). These studies suggest that the formation of the HSF-hsp70 complex correlates with increased intracellular levels of hsp 70 .

\section{Exogenous, wild-type hsp70 associates with HSF}

Results shown in Figure 3 revealed that extracts from $\mathrm{K} 562$ cells heat-shocked at $42^{\circ} \mathrm{C}$ for $10 \mathrm{~min}$ contain high levels of in vivo-activated HSF and that the anti-hsp70 antibody had no detectable effect on the gel mobility of the HSF-HSE complex. We examined whether this HSFHSE complex would associate with exogenous hsp70. Whole-cell extracts from cells heat-shocked for $10 \mathrm{~min}$ were incubated with increasing amounts of purified recombinant hsp70 and then subjected to gel mobility- 
A

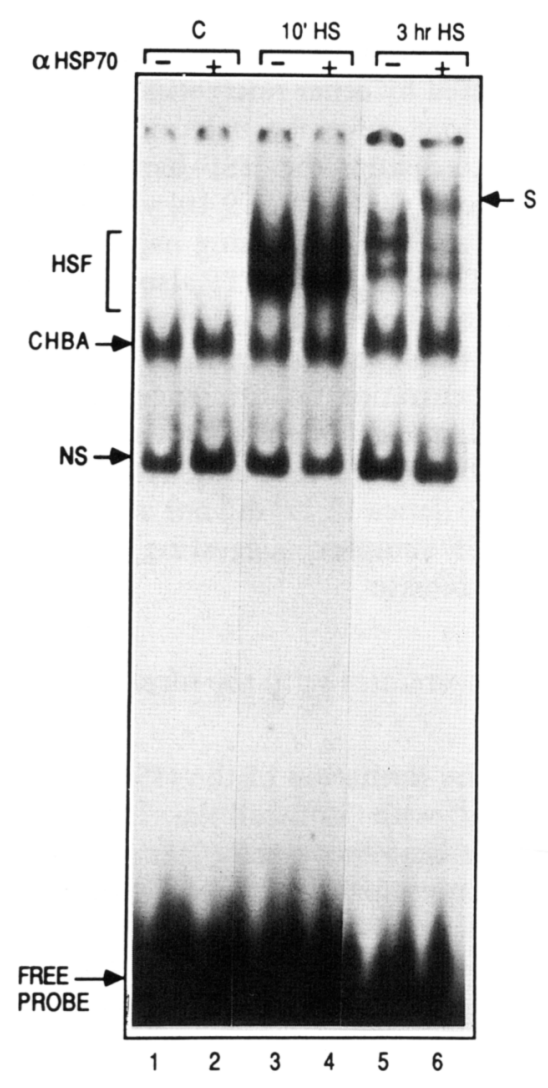

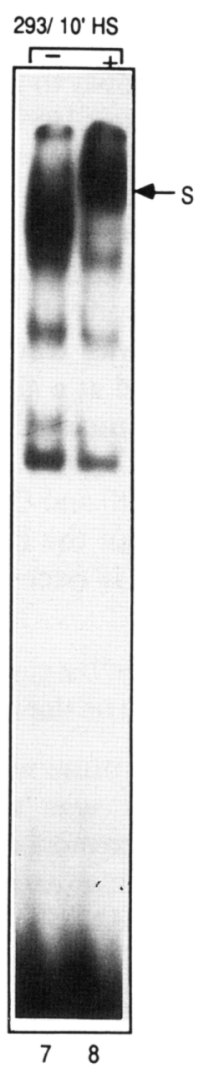

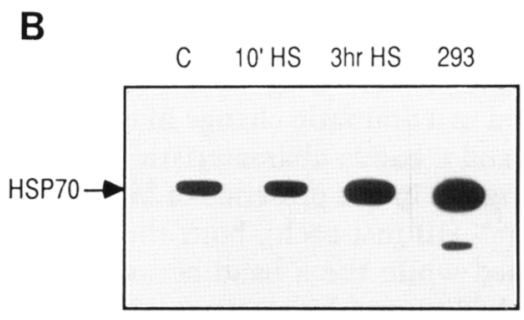

Figure 3. Association of hsp70 with HSF correlates with the level of hsp70 in the cell. (A) Gel mobility-shift analysis of HSF-HSE complex in the presence of anti-hsp70 antibody. Gel mobility-shift assays were performed with whole-cell extracts prepared from K562 cells (lanes 1-6) or 293 cells (lanes 7,8). Extracts were prepared from non-heat-shocked cells (lanes 1,2), from cells heat-shocked for 10 min (lanes 3,4,7,8), or from cells heat-shocked for $3 \mathrm{hr}$ (lanes 5,6). K562 cells were heat-shocked at $42^{\circ} \mathrm{C}$, and 293 cells were heat-shocked at $43^{\circ} \mathrm{C}$. Even-numbered lanes contain anti-hsp70 antibody C92 $1+1$. Complexes due to nonspecific (NS) DNA-binding proteins, constitutive HSE-binding activity (CHBA), and HSF are marked. The $S$ band represents the supershifted complex. (B) Western blot analysis of hsp70 levels in K562 and 293 cells. Cell extracts from non-heat-shocked (lane 1), $10 \mathrm{~min}$ heat-shocked (lane 2), 3 hr heat-shocked (lane 3) $\mathrm{K} 562$ cells, and 10 min heat-shocked 293 cells (lane 4) were electrophoresed on a SDS-PAGE gel and probed with C92. shift analysis. As shown in Figure 4, the addition of 0.2-8 $\mu \mathrm{g}$ of hsp70 decreased the mobility of the HSF-HSE complex in a concentration-dependent fashion (lanes 2-6). To determine whether exogenous hsp 70 was associated with HSF in these samples, anti-hsp70 antibody was added (+ lanes). The addition of $0.2 \mu \mathrm{g}$ of hsp70 was sufficient to form an hsp70-HSF complex that was recognized by anti-hsp70 antibody (lane 9), resulting in the formation of a supershifted complex. Addition of higher levels of hsp 70, from 2 to $4 \mu \mathrm{g}$, resulted in nearly complete complex formation with all of the HSF because all of the HSF-HSE complexes were supershifted in the pres-
Figure 4. Exogenous hsp70 associates with HSFHSE complex. Whole-cell extracts from $10 \mathrm{~min}$ heat-shocked $\mathrm{K} 562$ cells were incubated with increasing amounts $(0.2-8 \mu \mathrm{g})$ of purified hsp 70 protein (lanes 2-6). Anti-hsp70 antibody was added to samples containing $0-4 \mu \mathrm{g}$ of the hsp 70 protein (lanes 8-13). Anti-mouse IgG was added to the sample containing $4 \mu \mathrm{g}$ of hsp70 (lane 14). Binding reactions were done in the presence of 100 -fold excess of competitor DNA in lanes 7 and 13.

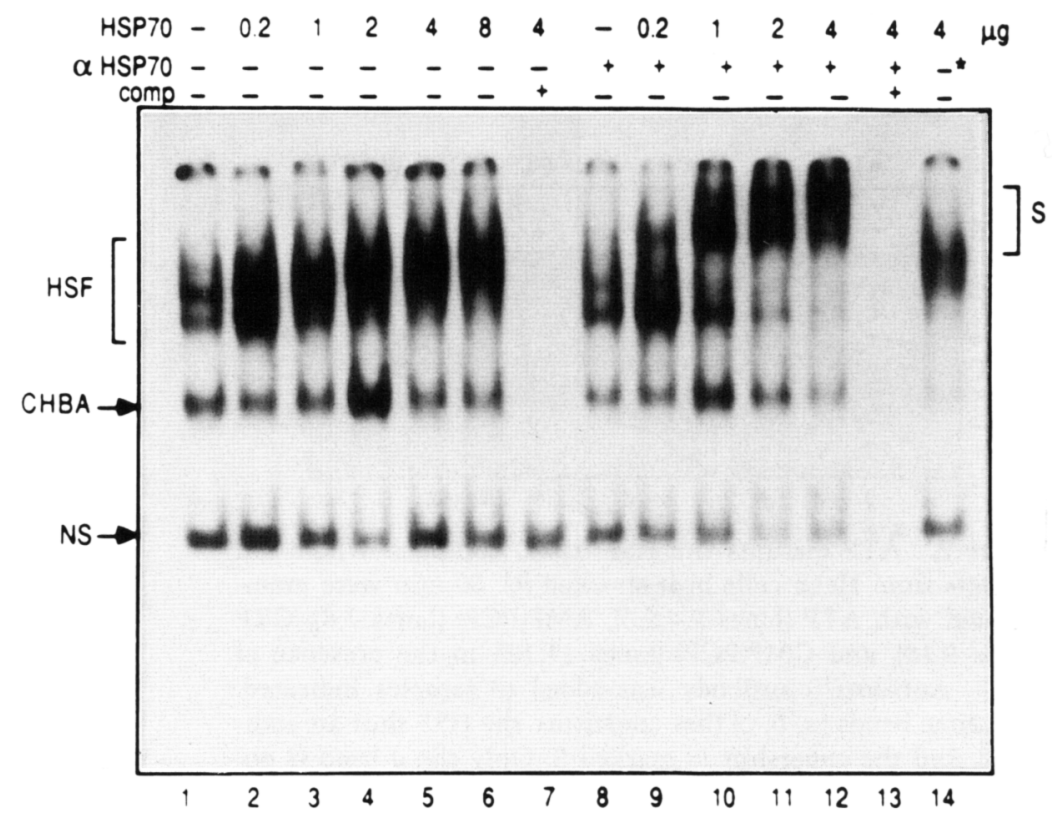


ence of anti-hsp70 antibody (lanes 11 and 12). These results demonstrate that exogenous hsp 70 associates with HSF.

To determine which region of hsp70 was necessary for its association with HSF, we used two deletion mutants of hsp70: an amino-terminal deletion that retains the peptide-binding domain (NSB), and a carboxy-terminal deletion that retains the ATP-binding domain (SMA; Milarski and Morimoto 1989) (Fig. 5A). The ability of NSB to bind to a peptide column and of SMA to bind to ATP was demonstrated previously (Milarski and Morimoto 1989; M. Myers, unpubl.). Each polypeptide was overexpressed in E. coli and purified (Fig. 5B). To determine whether these deletion mutants of hsp 70 would interact with HSF, 2, 8, and $20 \mu \mathrm{g}$ of either SMA or NSB were preincubated with whole-cell extracts and the gel mobility-shift assay was performed (Fig. 5C). Surprisingly, neither high levels of SMA nor NSB affected the mobility of the HSF-HSE complex. As observed previously (Fig. 4), the addition of wild-type hsp70 resulted in a noticeable upshift of the HSF-HSE complex, whereas BSA, used as control, did not affect the mobility of the HSF-HSE complex. Because the C92 antibody failed to recognize the deletion mutants by Western blot analysis (data not shown), experiments with antibody for detection of a supershifted complex were not performed.

Exogenous hsp70 interferes with the in vitro activation of HSF

To address the potential regulatory effects of hsp70 on
HSF activity, we took advantage of a simple in vitro assay in which HSF can be activated in a cytoplasmic extract subjected to elevated temperatures or treatment with urea, $2 \%$ NP-40, or exposure to low pH (Larson et al. 1988; Mosser et al. 1990). An S-100 extract from control HeLa cells contained no detectable HSE-binding activity (Fig. 6, lane 2), whereas treatment with 2\% NP-40 at $37^{\circ} \mathrm{C}$ for $1 \mathrm{hr}$ resulted in appreciable levels of activated HSF (lane 1). The addition of recombinant hsp70 to the S-100 extract completely blocked the activation of HSF (lanes 4,6), whereas addition of BSA (lane 5) or buffer (lane 3) had no effect. Addition of hsp70 does not cause HSF degradation (data not shown). Identical results were obtained when heat was used instead of NP-40 to in vitro-activate HSF (data not shown). The inhibitory effect of hsp70 on HSF activation was detected only if hsp70 was depleted of ATP following its purification by ATP agarose chromatography (data not shown). Addition of ATP prevented the inhibitory effect of hsp70 (lane 7). In contrast, addition of the nonhydrolyzable analog $\mathrm{AMP}(\mathrm{PCP})$ did not reverse the inhibitory effect of hsp70 (lane 8). These results suggest that hsp70 may have a negative regulatory role in the process of HSF activation from a non-DNA-binding form to a DNA-binding form.

To determine whether hsp70 had any effect on the DNA-binding activity of in vitro-activated HSF, HSF was first activated in vitro (by heat or NP-40) and hsp70 was then added. Exogenous hsp70 forms a complex with in vitro-activated HSF as revealed by a change in the mobility of the HSF-HSE shift but does not inhibit the

\section{A}

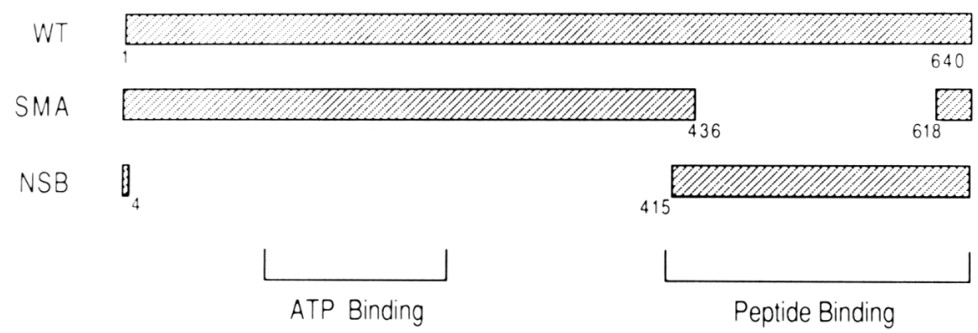

C

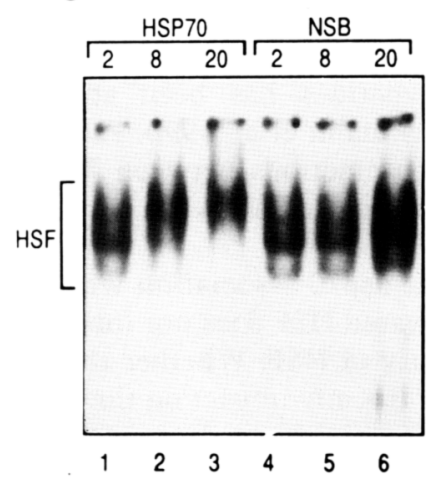

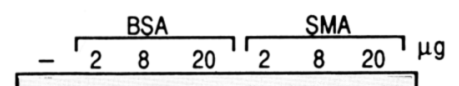

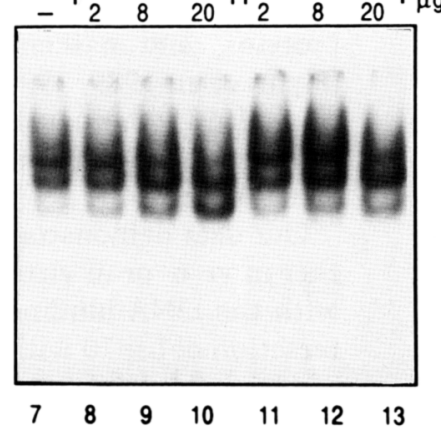

B

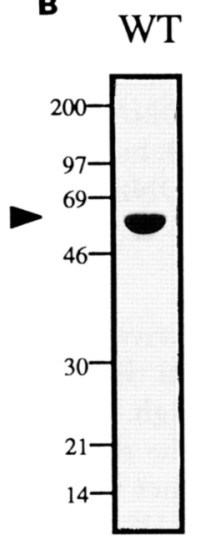

Figure 5. HSF does not associate with carboxy-terminal or amino-terminal deletion mutants of hsp70. (A) Schematic of wild-type hsp70 and the two mutants-SMA, which contains a carboxy-terminal deletion from amino acids 436-618, and NSB, which contains an amino-terminal deletion from amino acids 4-415-are shown. The regions corresponding to the ATP-binding domain and the peptide-binding domain of hsp70 are indicated. $(B)$ Silverstained SDS-PAGE gels of purified wild-type hsp70 (WT), SMA, and NSB. Each protein was purified from E. coli cells, where each construct was overexpressed. For details of the recombinant constructs, overexpression, and purification procedure, see Materials and methods. $(C)$ Gel mobility-shift analysis of HSF-HSE complex in the presence of wild- type and mutant hsp70 proteins. Amounts of 2, 8, and $20 \mu \mathrm{g}$ of wild type (lanes 1-3), NSB (lanes 4-6), BSA (lanes 8-10), and SMA (lanes 11-13) were incubated with whole-cell extracts, and gel-shift assays were performed as described in Materials and methods. Exogenous protein was not added to the sample in lane 7. 


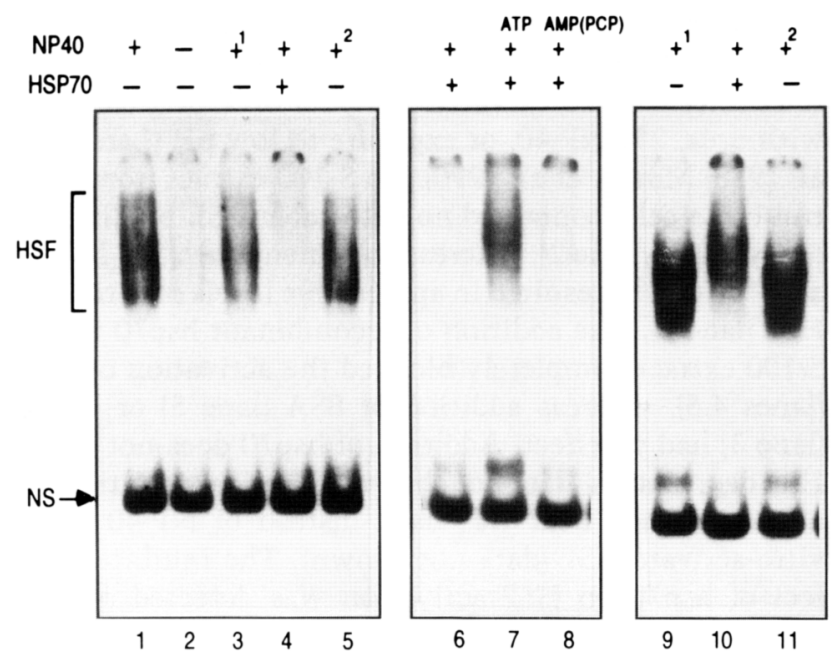

Figure 6. In vitro activation of HSF is inhibited by hsp70. Cytoplasmic extracts (S-100) from non-heat-shocked cells were treated with $2 \%$ NP-40 to in vitro-activate HSF and analyzed in gel-shift assays as described. Cytoplasmic extracts from control cells were incubated with buffer (lanes 3,9), with $6 \mu \mathrm{g}$ of hsp70 (lanes $4,6,10$ ), or with $6 \mu \mathrm{g}$ of BSA (lanes 5,11), before (lanes 3-8) or after (9-11) the in vitro activation. Six micrograms of hsp70 was added to S-100 along with $10 \mathrm{mM} \mathrm{ATP} / \mathrm{Mg}^{2+}$ (lane 7) or along with $10 \mathrm{mM} \mathrm{AMP}(\mathrm{PCP}) / \mathrm{Mg}^{2+}$ (lane 8$)$ before in vitro activation. Exogenous protein was not added to the sample in lane 1. The sample in lane 2 was not treated with NP-40.

DNA-binding activity of in vitro-activated HSF (Fig. 6, lane 10). These results are consistent with our observation that the DNA-binding ability of the in vivo-activated HSF is not altered by hsp70 (Fig. 4). Our data suggest that hsp70 interferes with the activation of HSF from a non-DNA-binding form to a DNA-binding form; but once the factor acquires DNA-binding activity, hsp70 does not block its binding to DNA.

\section{Discussion}

In this study we demonstrate that in vivo-activated HSF is found in a complex with hsp70 and that this association is detected in cells containing high levels of hsp70. Complexes of HSF with hsp70 can be reconstituted in vitro with recombinant hsp70. The fact that the association of in vivo- or in vitro-activated HSF with hsp70 is detected by gel mobility-shift assay reveals that hsp70 does not interfere with the ability of activated HSF to interact with DNA. However, we find that addition of hsp70 to cytoplasmic extracts from control (non-heatshocked) cells prevents the in vitro conversion of HSF from a non-DNA-binding form to a DNA-binding form. This suggests that hsp70 may play a regulatory role in HSF activation. The involvement of hsp70 in the activation of HSF provides a mechanism for the autoregulation of $h s p 70$ expression in human cells.

\section{HSF-hsp70 complex is disrupted by ATP}

Consistent with several studies where ATP has been shown to be necessary for the disruption of $70-\mathrm{kD}$ heat shock proteins from substrates with which they associate (Pelham 1986; Clarke et al. 1988; Flynn et al. 1989; Kost et al. 1989; Beckmann et al. 1990; Palleros et al. 1991), we show that ATP and other hydrolyzable nucleotide triphosphates disrupt the HSF-hsp70 complex. Similar to our findings, several nucleotides (ATP, GTP, CTP, and UTP) were shown to dissociate a $70-\mathrm{kD}$ heat shock protein from SV40 large $\mathrm{T}$ antigen (Sawai and $\mathrm{Bu}$ tel 1989). Nonhydrolyzable analogs of ATP and GTP, $\mathrm{AMP}(\mathrm{PCP})$ and $\mathrm{GMP}(\mathrm{PCP})$, respectively, were unable to disrupt the HSF-hsp70 complex, suggesting that hydrolysis is required for the dissociation of hsp 70 from HSF.

Our studies offer an explanation for the observation of multiple HSF-HSE bands detected in a gel mobility-shift analysis. HSF exists in distinct complexes; the faster migrating a complex is free of hsp70, that is, it cannot be disrupted with ATP or supershifted by anti-hsp70 antibodies. The slower migrating bands are disrupted by ATP; they represent HSF in association with hsp70 and possibly other proteins.

\section{HSF associates with wild-type recombinant hsp 70}

Our data demonstrate that an HSF-hsp70 complex is detected in cells that accumulate high levels of hsp70. We extended this observation by demonstrating that an HSF-hsp70 complex would form in vitro upon addition of exogenous recombinant hsp70. In these studies only the intact hsp70 was capable of associating with HSF. The carboxy-terminal region of hsp70, which was shown to be sufficient to bind peptides in vitro (NSB polypeptide; M. Myers, unpubl.), failed to associate with HSF. An amino-terminal region that lacks the peptide-binding domain, but retains the ATP-binding domain (SMA construct), was also unable to complex with HSF. The failure of NSB mutant to form a complex with HSF suggests that the nature of hsp70 interaction with HSF is different than the association of hsp70 with short peptides. Binding to a native protein may necessitate multiple interactions with both domains of hsp70 and/or may require a certain conformation of hsp70 that is disrupted in the truncated mutant forms. Although the association of $70-$ $\mathrm{kD}$ heat shock proteins with short peptides, unfolded proteins, and nascent polypetides has been studied (Flynn et al. 1989, 1991; Beckmann et al. 1990; Palleros et al. 1991), the nature of interactions between $70-\mathrm{kD}$ heat shock proteins and native proteins has not yet been characterized.

Our data demonstrate that hsp70 association with either in vivo- or in vitro-activated HSF does not interfere with the DNA-binding ability of HSF. Whether the interaction of hsp70 with HSF has any impact on the transcriptional activity of HSF remains to be demonstrated. Many eukaryotic transcription factors possess separate domains for DNA-binding and transcriptional activation, and each function can often be regulated independently (for review, see Mitchell and Tiian 1989; Frankel and Kim 1991). Although the transcriptional activation 
domain in HSF from higher eukaryotes has not yet been identified, it is possible that hsp70 modulates this aspect of HSF function when present in the HSF-DNA complex. Some of our observations are consistent with this possibility. In 293 cells, HSF-mediated transcriptional induction of the hsp70 gene is only 7-fold (B. Phillips, unpubl.), compared with a 30 -fold induction in HeLa or K562 cells. These differences in the fold of induction may be due in part to the fact that HSF is already associated with hsp70 at early times of heat shock in 293 cells but not in HeLa or K562 cells (Fig. 3).

\section{hsp70 blocks the in vitro activation of HSF}

The experiments that suggest a potential role for hsp 70 in the regulation of HSF are based on the ability of exogenous hsp70 to block the in vitro activation of HSF; exogenous hsp70 prevents the non-DNA-binding form of HSF from acquiring DNA-binding activity. Whether the inhibitory effect of hsp70 in in vitro activation of HSF is achieved through a direct association of hsp70 with HSF remains to be determined. Yet the observation that ATP and not $\mathrm{AMP}(\mathrm{PCP})$ can reverse the inhibitory effect of hsp70, presumably by dissociating the HSF-hsp70 complex, supports the possibility that the inhibition is through direct interaction.

Our demonstration that hsp 70 blocks the activation of HSF in vitro is consistent with a hypothesis that hsp70 may maintain HSF in an inactive form in non-heatshocked cells. Two distinct HSF genes have been identified in human and mouse cells: HSF1 and HSF2 (Rabindran et al. 1991; Sarge et al. 1991; Schuetz et al. 1991). HSF1, which is the primary component of HSE-binding activity in heat-shocked cells, exists in a non-DNA-binding form in non-heat-shocked cells (K.D. Sarge et al., in prep.). Moreover, the recombinant mouse HSF1 translated in vitro in a rabbit reticulocyte lysate does not bind to DNA unless it is heat-shocked (Sarge et al. 1991). This failure of DNA binding is not an intrinsic property of the HSF protein, as recombinant Drosophila, mouse, and human HSF 1 proteins expressed in E. coli bind DNA constitutively (Clos et al. 1990; Rabindran et al. 1991; Sarge et al. 1991). One possible explanation for this discrepancy is that eukaryotic cells contain a regulatory protein that could hinder the DNA-binding ability of HSF. Such a possibility has been proposed previously (Clos et al. 1990), and it was speculated that heat shock proteins may participate in the suppression of HSF activity /Clos et al. 1990). Our results support this view and suggest that hsp 70 may play a role in the negative regulation of HSF. In cells that do not express hsp70 constitutively, such as rodent cells and Drosophila, other members of the $70-\mathrm{kD}$ heat shock gene family [such as heat shock constitutive (hsc70)] may fulfill this function.

Comparison of the predicted amino acid sequences of cloned HSFs revealed two conserved regions: a DNAbinding domain and an array of hydrophobic heptad repeats (leucine zippers) that are implicated in the oligomerization of HSF through the formation of coiled coil motifs (Sorger and Pelham 1987; Wiederrecht et al. 1988; Sorger and Nelson 1989; Clos et al. 1990; Scharf et al. 1990; Jakobsen and Pelham 1991; Rabindran et al. 1991; Sarge et al. 1991; Schuetz et al. 1991). Yeast HSF contains three leucine zippers while HSFs from higher eukaryotes contain four. Because yeast HSF binds DNA constitutively (Sorger et al. 1987; Jakobsen and Pelham 1988), it was proposed by Rabindran et al. (1991), that the fourth leucine zipper may be involved in maintaining HSF in an inactive form under nonshock conditions. It would be of great interest to determine whether hsp70 interacts with HSF through this fourth zipper.

\section{A model for HSF activation}

We propose a model for HSF activation in human cells that incorporates the data presented here and observations from other laboratories (Fig. 7). As some of the points are speculative, we offer this model as a means to consolidate and unify current observations. According to this model, HSF shown here as a monomer associates with hsp70 in non-heat-shocked cells. This association prevents the activation of HSF, possibly by the maintenance of HSF in a non-DNA-binding state. During heat shock, the generation of denatured and malfolded proteins creates a large pool of new substrates for hsp 70 (Goff and Goldberg 1985; Ananthan et al. 1986; Parsell and Sauer 1989|, which compete for hsp70 binding, resulting in the release of HSF from hsp70. The released HSF oligomerizes, binds DNA, and acquires transcriptional activity. Results from our laboratory support a multistep activation pathway for HSF (Jurivich et al. 1992). Activated HSF induces transcription of heat shock genes, which leads to a high level of synthesis and accumulation of heat shock proteins in the cell. Excess hsp70 associates with activated HSF; this association may impair the transcriptional activity of HSF. hsp70 may also resume its association with inactive HSF and prevent further activation. Hsp 70 could also participate in the

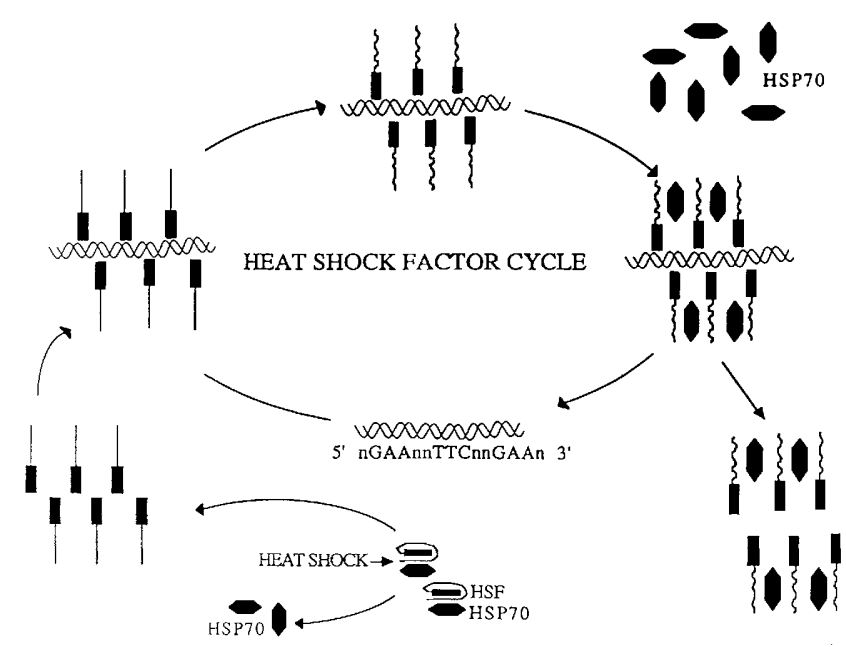

Figure 7. A model for HSF activation. (See Discussion.) 
conversion of the hexameric HSF to its monomeric state similar to the role dnaK ( $E$. coli analog of hsp 70) plays in the conversion of dimeric repA protein to its monomeric form (Wickner et al. 1991).

This model accommodates several observations in the field and provides an autoregulatory loop for hsp70 synthesis. A homeostatic mechanism in which the level of hsp70 dictates the activation of heat shock protein synthesis was originally proposed by DiDomenico et al. (1982). Modulation of hsp70 synthesis by changes in intracellular hsp70 levels was demonstrated recently in Drosophila (Solomon et al. 1991). In both E. coli and yeast, mutations in hsp70 result in overexpression of heat shock genes, suggesting that hsp70 is the negative regulator (Tilly et al. 1983; Craig and Jakobsen 1984; Straus et al. 1989; Craig and Gross 1991). In yeast, the target for negative regulation appears to be HSF (Boorstein and Craig 1990). The E. coli heat shock proteins DnaK, DnaJ, and GrpE were shown to negatively regulate $\sigma^{32}$, the E. coli heat shock factor (Tilly et al. 1989; Straus et al. 1989, 1990). We have observed that in human $\mathrm{K} 562$ cells, a $20-\mathrm{min} 42^{\circ} \mathrm{C}$ heat shock, followed by a 3 -hr recovery at $37^{\circ} \mathrm{C}$ to allow accumulation of heat shock proteins, represses the activation of HSF in response to a second $42^{\circ} \mathrm{C}$ heat shock; a more severe $44^{\circ} \mathrm{C}$ heat shock is necessary to reactivate HSF ( $\mathrm{K}$. Abravaya, unpubl.). Similarly, in 293 cells that have high levels of hsp70 (Fig. 3), HSF cannot be activated at $42^{\circ} \mathrm{C}$; a $43^{\circ} \mathrm{C}$ heat shock is required (B. Phillips, unpubl.). These results suggest that HSF activation is negatively regulated by hsp70 in human cells. The recent demonstration that dnaK interacts with $\sigma^{32}$ raises the possibility that the negative regulation in $E$. coli occurs through direct protein-protein interaction (C. Georgopolous, pers. comm.). Our data provide the first evidence that hsp70 interacts with HSF in eukaryotes and offer insight into the mechanism by which autoregulation may be achieved.

A mechanism of negative regulation where transcriptional activators form heteromeric complexes with inhibitory proteins has been shown to play a major role in a number of cellular processes, including development, differentiation, signal transduction, and malignant transformation. One example is $I \kappa B$, which associates with NF- $k B$ and prevents its translocation to the nucleus (Baeuerle and Baltimore 1988; Urban and Baeuerle 1990). Interestingly, both NF- $\kappa \mathrm{B}$ and HSF can be activated in vitro to bind DNA upon addition of detergents (Baeuerle and Baltimore 1988). The activation of NF-кB results from the disruption of the NF- $\mathrm{B}$ B-IкB complex. We hypothesize that activation of HSF may likewise result from the disruption of the HSF-hsp70 complex. Other examples of negative regulators include Id, which associates with a number of helix-loop-helix family proteins including MyoD, the muscle determination protein, and prevents them from binding DNA (Benezra et al. 1990), and I-POU, which forms a heterodimer with another POU domain protein and prevents its binding to DNA /Treacy et al. 1991). Likewise, the Fos and Jun oncoproteins that form homo- and heterocomplexes through leucine zipper regions are inhibited by IP-1 (Auwerx and Sassone-Corsi
1991). A naturally occurring truncated form of FosB also inhibits Fos/Jun activity (Nakabeppu and Nathans 1991), presumably by competing with wild-type Fos protein for dimerization with Jun. Although the mechanisms of negative regulation in these cases may differ, the common theme is that it is achieved through protein-protein interactions. Regulation of transcription factors through interactions with inhibitory proteins provides the cell with an additional level of control; and in the case of HSF-hsp70, where the activator interacts with the product of its target gene, this interaction may mediate autoregulation.

\section{Materials and methods}

\section{Cell culture and heat shock conditions}

HeLa S3 cells were grown in Joklik's medium supplemented with $5 \%$ calf serum; growth and heat shock conditions were described previously (Abravaya et al. 1991a,b). Erythroleukemia cells (K562) were grown in RPMI 1640 medium supplemented with $10 \%$ fetal calf serum in a humidified $7 \% \mathrm{CO}_{2}$ atmosphere at $37^{\circ} \mathrm{C}$. The 293 cells, a human embryonic kidney cell line transformed by and expressing the El region of adenovirus 5 (Graham and Smiley 1977), were maintained as monolayers in Dulbecco's modified Eagle medium (DMEM), supplemented with $5 \%$ calf serum. K562 and 293 cells were heat-shocked at $42^{\circ} \mathrm{C}$ and at $43^{\circ} \mathrm{C}$ respectively, in a water bath for various times.

\section{Gel mobility-shift assay and addition of antibodies} and nucleotides

Conditions for the gel mobility-shift assay, the binding buffer, a description of the ${ }^{32}$ P-labeled HSE oligonucleotide, and preparation of whole-cell extracts were as published previously (Mosser et al. 1988). Anti-hsp70 antibody (C92) was purchased from Amersham, diluted $1: 1$ in PBS containing 10\% BSA and $1 \mu \mathrm{l}$ of the dilution added to $10 \mu \mathrm{g}$ of whole-cell extracts. The mixture was incubated at $37^{\circ} \mathrm{C}$ for $10 \mathrm{~min}$ before addition of the binding buffer containing the HSE oligonucleotide. Nucleotides ATP and GTP were purchased from Sigma; AMP(PCP) and GMP(PCP) were purchased from Boehringer Mannheim. The nucleotides were diluted in $10 \mathrm{~mm}$ Tris, and the $\mathrm{pH}$ was adjusted to 7 . Nucleotides were added at indicated concentrations along with $10 \mathrm{mM} \mathrm{Mg}^{2+}$ to $10 \mu \mathrm{g}$ of whole-cell extracts, incubated at $37^{\circ} \mathrm{C}$ for $15 \mathrm{~min}$ before the addition of the binding buffer. In experiments where both anti-hsp70 antibody and nucleotides were added, the nucleotides were added first, incubated with whole-cell extracts for $10 \mathrm{~min}$ at $37^{\circ} \mathrm{C}$. The antihsp 70 antibody was then added and incubated at $37^{\circ} \mathrm{C}$ for an additional $15 \mathrm{~min}$ before the addition of the binding buffer. Competition reaction mixtures contained $100 \times$ excess of nonradioactive HSE oligonucleotide.

\section{Western blot analysis}

Twenty micrograms of whole-cell extracts was electrophoresed on a $10 \%$ SDS-PAGE gel and transferred to nitrocellulose. The filter was blocked with PBS containing $5 \mathrm{mg} / \mathrm{ml}$ of BSA and incubated with the C92 monoclonal anti-hsp70 antibody ( $1: 1000$ dilution in PBS plus $5 \mathrm{mg} / \mathrm{ml}$ of BSA) for $1 \mathrm{hr}$. C92 specifically recognizes hsp70 and not the other members of the 70-kD heat shock proteins (Welch and Mizzen 1988). Following 
three 10-min washes with PBS/0.1\% Tween 20, the blot was incubated with horseradish peroxidase-conjugated goat antimouse IgG secondary antibodies (Cappel). Blots were then washed three times for $5 \mathrm{~min}$ with $\mathrm{PBS} / 0.3 \%$ Tween 20 , followed by three times for $5 \mathrm{~min}$ with PBS $/ 0.1 \%$ Tween 20 . hsp 70 was then detected by use of the enhanced chemiluminescence (ECL) according to the manufacturer's specifications (Amersham).

\section{Cloning of wild-type and mutant hsp70}

The human hsp70 gene (Hunt and Morimoto 1985) was overexpressed in $E$. coli by inserting the coding sequences into the $\mathrm{T} 7$ expression vector pET-1 la (Studier et al. 1990). The unique ScaI site in the $3{ }^{\prime}$-untranslated region of the $h s p 70$ gene in plasmid $\mathrm{pH} 2.3$ was converted to a BamHI site by digestion with ScaI and ligation to BamHI linkers. The modified $\mathrm{pH} 2.3$ plasmid was then cleaved with $B a m H I$, and the $2.1-\mathrm{kb} B a m H I$ fragment containing the $h s p 70$-coding sequences was gel-purified and subcloned into pGEM-1 to yield pGEM-hsp70-Bam. The human $h s p 70$ gene was then directionally cloned into pET-11a by digesting pGEM-hsp70-Bam with Ball (located at the second codon of $h s p 70$ ) and BamHI and isolating the 2.04-kb BallBamHI fragment. pET-11a was treated with Nhel, blunted with mung bean nuclease, cleaved with BamHI, dephosphorylated with alkaline phosphatase, gel-purified, and ligated to the $h s p 70$-coding sequences. This cloning scheme places the $h s p 70$ gene under the control of a strong T7 RNA polymerase responsive promoter and results in the production of a recombinant human hsp70 protein that does not contain any foreign amino acids. The same cloning scheme was used to overexpress the SMA mutant that was constructed previously in our laboratory (Milarski and Morimoto 1989). The NSB mutant was constructed by sequential treatment of pGEM-hsp 70-tag (Milarski and Morimoto 1989/ with SacII, mung bean nuclease, BclI, and T4 DNA polymerase. The treated DNA was then recircularized with T4 DNA ligase and transformed into DH-1. This deletion scheme removes the nucleotide sequences encoding amino acids 5-414. The NSB mutant was expressed in E. coli as a fusion protein with glutathione $S$-transferase (GST) by use of the pGEX-2T system (Smith and Johnson 1988). pGEX-2T encodes a thrombin cleavage site at the fusion junction. To generate the NSB-GST fusion, the NSB mutant was cleaved with Ball and $S c a I$ and the $0.88-\mathrm{kb}$ fragment was gel-purified for insertion into pGEX-2T. pGEX-2T was digested with BamHI, blunted with mung bean nuclease, dephosphorylated, gel purified, and ligated to the NSB-coding sequences.

\section{Expression and purification of wild-type and mutant hsp 70}

Following the cloning, the pET-WT-hsp70 and pET-SMA DNAs were transformed into BL21(DE3), which contains the T7 polymerase gene under IPTG-inducible control (Studier et al. 1990). Transformants of pET-WT, pET-SMA, and pGEX-NSB were grown in LB-Amp, induced with 0.4 mM IPTG at an $\mathrm{OD}_{550}$ of 0.6 , and grown at $37^{\circ} \mathrm{C}$ for $3 \mathrm{hr}$. Cell pellets of induced cultures were resuspended in lysis buffer [ $20 \mathrm{mM}$ HEPES (pH 8), 0.1 mM EDTA, $0.016 \mathrm{M} \mathrm{NaCl}, 0.5 \mathrm{mg} / \mathrm{ml}$ lysozyme, and the protease inhibitors leupeptin $\{1 \mu \mathrm{g} / \mathrm{ml})$, pepstatin $\mathrm{A}(1 \mu \mathrm{g} / \mathrm{ml})$, and PMSF (1 mM)] at $3 \mathrm{ml} / \mathrm{g}$ of wet cells, and incubated on ice for 30 min. Protoplasts were lysed by freeze/thawing and sonication, and the lysate was then centrifuged for $1 \mathrm{hr}$ at $123,000 \mathrm{~g}$. The supernatant was supplemented with DTT (1 mM), aliquoted, frozen in liquid nitrogen, and stored at $-70^{\circ} \mathrm{C}$. Both wild type and SMA were purified by a combination of anion-exchange chromatography and ATP-agarose affinity chromatography. Crude extract was loaded onto a 20-ml DEAE-Sepharose CL6B column (Pharmacia) and eluted with a $0-0.1 \mathrm{M} \mathrm{NaCl}$ gradient over 5 column volumes, followed by 5 column volumes at $0.1 \mathrm{M}$ $\mathrm{NaCl}, 2$ column volumes at $0.1 \mathrm{M} \mathrm{NaCl}$, followed by a $0.1-0.2 \mathrm{M}$ $\mathrm{NaCl}$ gradient over 5 column volumes. This shallow gradient elutes most of the recombinant human wild type and SMA before the E. coli hsp70 homolog dnaK. Fractions containing wild type or SMA were pooled and loaded onto a $10-\mathrm{ml} \mathrm{ATP-agarose}$ column (Sigma; C-8 linkage), washed with $0.7 \mathrm{M} \mathrm{NaCl}$, returned to $0.05 \mathrm{M} \mathrm{NaCl}$, and eluted with $2 \mathrm{ml}$ of column buffer containing $50 \mathrm{mM} \mathrm{Mg-ATP.} \mathrm{Wild-type-} \mathrm{or} \mathrm{SMA-containing} \mathrm{fractions}$ were pooled, concentrated by ultrafiltration in Centriprep-30 (Amicon), and dialyzed extensively against $50 \mathrm{mM}$ HEPES (pH $7.21,0.1 \mathrm{~mm}$ EDTA, and $50 \mathrm{~mm} \mathrm{NaCl}$ to eliminate the ATP.

Crude extracts containing NSB-GST protein were supplemented to $1 \%$ Triton X-100 and loaded onto a 10 -ml glutathione-Sepharose column (Pharmacia). After washing with buffer containing $0.7 \mathrm{M} \mathrm{NaCl}$, the fusion protein was eluted with $2 \mathrm{ml}$ of buffer containing $100 \mathrm{~mm}$ glutathione $(\mathrm{pH} 7.2)$. The fusion protein was concentrated by ultrafiltration in Centriprep-30, and desalted over a 10-ml G-25 Sephadex column (Pharmacia) to remove the free glutathione. The void fractions were pooled and concentrated by ultrafiltration, and the protein concentration was determined by use of the BCA assay (Pierce). The fusion protein was then cleaved with thrombin (Sigma) for $15 \mathrm{~min}$ at $25^{\circ} \mathrm{C}$ [thrombin/fusion ration of $1: 2500$ (wt/wt)]. The cleaved material was then passed over glutathione-agarose again to remove the GST. Flowthrough fractions containing NSB were pooled and concentrated in Centricon-30 (Amicon).

\section{In vitro activation of $H S F$}

Cytoplasmic cell extracts (S-100) were prepared as described previously (Mosser et al. 1990). Thirty micrograms of S-100 was incubated with NP-40 to give a final concentration of $2 \%$, at $37^{\circ} \mathrm{C}$ for $1 \mathrm{hr}$ to activate HSF. After activation, the binding reaction was performed and samples were electrophoresed as described previously (Mosser et al. 1990). In samples where hsp70 was added, $6 \mu \mathrm{g}$ of ATP-depleted recombinant hsp70, purified as described above, was incubated with S-100 for 15 min at $37^{\circ} \mathrm{C}$ before or after the activation with NP-40. As controls, $6 \mu \mathrm{g}$ of BSA or equivalent volume of buffer (hsp70 dialysis buffer) was added instead of hsp70. ATP-Mg or AMP(PCP)/Mg (10 mM of each) was added along with hsp70 to the S-100 extract.

\section{Acknowledgments}

We thank Sue Fox for excellent technical assistance, Carla Amici and Lea Sistonen for providing cell extracts for the initial phase of this work, and William Studier for sharing the T7 expression vector. We thank Benette Phillips, Barbara Wu, Jonathan Widom, and all members of our laboratory for critically reviewing the manuscript. These studies were supported by grants from the National Institutes of Health (NIH), March of Dimes Foundation, and an American Cancer Society Faculty Research Award. K.A. was supported by an Individual National Research Service Award (NRSA) from NIH and a postdoctoral fellowship from the American Cancer Society; M.P.M. was supported by an NIH Predoctoral Training Grant, and S.P.M. was supported by an Individual NRSA Postdoctoral Fellowship. 
The publication costs of this article were defrayed in part by payment of page charges. This article must therefore be hereby marked "advertisement" in accordance with 18 USC section 1734 solely to indicate this fact.

\section{References}

Abravaya, K., B. Phillips, and R.I. Morimoto. 1991a. Heat shockinduced interactions of heat shock transcription factor and the human hsp70 promoter examined by in vivo footprinting. Mol. Cell. Biol. 11: 586-592.

- 1991b. Attenuation of the heat response in HeLa cells is mediated by the release of bound heat shock transcription factor and is modulated by changes in growth and heat shock temperatures. Genes \& Dev. 5: 2117-2127.

Amin, J., J. Ananthan, and R. Voellmy. 1988. Key features of heat shock regulatory elements. Mol. Cell. Biol. 8: 37613769.

Ananthan, J., A.L. Goldberg, and R. Voellmy. 1986. Abnormal proteins serve as eukaryotic stress signals and trigger the activation of heat shock genes. Science 232: 522-524.

Auwerx, J. and P. Sassone-Corsi. 1991. IP-I: A dominant inhibitor of fos/jun whose activity is modulated by phosphorylation. Cell 64: 983-993.

Baeuerle, P.A. and D. Baltimore. 1988. Activation of DNA-binding is an apparently cytoplasmic precursor of the NF-kB transcription factor. Cell 53: 211-217.

Beckmann, R.P., L.A. Mizzen, and W.J. Welch. 1990. Interaction of hsp70 with newly synthesized proteins: Implications for protein folding and assembly. Science 248: 850-854.

Benezra, R., R.L. Davis, D. Lockshon, D.L. Turner, and H. Weintraub. 1990. The protein Id: A negative regulator of helixloop-helix DNA binding proteins. Cell 61: 49-59.

Boorstein, W.R. and E.A. Craig. 1990. Transcriptional regulation of ssa3, an hsp70 gene from Saccharomyces cerevisae. Mol. Cell. Biol. 10: 3262-3267.

Brugge, J.S. 1986. Interaction of the Rous sarcoma virus protein pp $60^{\text {src }}$ with the cellular proteins pp50 and pp90. Curr. Top. Microbiol. Immunol. 123: 1-23.

Catelli, M.J., N. Binart, I. Jung-Testas, J.M. Renoir, E.E. Baulieu, J.R. Feramisco, and W.J. Welch. 1985. The common 90kD protein component of nontransformed " $8 \mathrm{~S}$ " steroid receptors is a heat shock protein. EMBO J. 4: 3131-3137.

Clarke, C.F., K. Cheng, A.B. Frey, R. Stein, P.H. Hinds, and A.J. Levine. 1988. Purification of complexes of nuclear oncogene p53 with rat and Escherichia coli heat shock proteins: In vitro dissociation of hsc 70 and dnaK from murine p53 by ATP. Mol. Cell. Biol. 8: 1206-1215.

Clos, J., J.T. Westwood, P.B. Becker, S. Wilson, K. Lambert, and C. Wu. 1990. Molecular cloning and expression of a hexameric Drosophila heat shock factor subject to negative reg. ulation. Cell 63: 1085-1097.

Craig, E. and C.A. Gross. 1991. Is hsp70 the cellular thermometer? Trends Biochem. Sci. 16: 135-140.

Craig, E.A. and K. Jakobsen. 1984. Mutations of the heat inducible 70 kilodalton genes of yeast confer temperature sensitive growth. Cell 38: 841-849.

DiDomenico, B.J., G.E. Bugaisky, and S. Lindquist. 1982. The heat shock response is self-regulated at both the transcriptional and posttranscriptional levels. Cell 31: 593-603.

Flynn, G.C., T.G. Chappell, and J.E. Rothman. 1989. Peptide binding and release by proteins implicated as catalysts of protein assembly. Science 245: 385-390.

Flynn, G.C., J. Pohl, M.T. Flocco, and J.E. Rothman. 1991. Peptide-binding specificity of the molecular chaperone BIP. $\mathrm{Na}$ - ture 353: 726-730.

Frankel, A.D. and P.S. Kim. 1991. Modular structure of transcription factors: Implications for gene regulation. Cell 65: 717-719.

Gething, M.J. and J. Sambrook. 1992. Protein folding in the cell. Nature 355: 33-45.

Goff, S.A. and A.L. Goldberg. 1985. Production of abnormal proteins in E. coli stimulates transcription of lon and other heat shock genes. Cell 41: 587-595.

Graham, F.L. and J. Smiley. 1977. Characteristics of a human cell line transformed by DNA from human adenovirus type 5. J. Gen. Virol. 36: 59-72.

Grossman, A.D., J.W. Erikson, and C.A. Gross. 1984. The htpR gene product of E. coli is a sigma factor for heat shock promoters. Cell 38: 383-390.

Grossman, A.D., D.B. Straus, W.A. Walter, and C.A. Gross. 1987. $\sigma^{32}$ synthesis can regulate the synthesis of heat shock proteins in Escherichia coli. Genes \& Dev. 1: 179-184.

Hinds, P.W., C.A. Finlay, A.B. Frey, and A.J. Levine. 1987. Immunological evidence for the association of $\mathrm{p} 53$ with a heat shock protein, hsc70, in p53-plus-ras-transformed cell lines. Mol. Cell. Biol. 7: 2863-2869.

Hunt, C.R. and R.I. Morimoto. 1985. Conserved features of eukaryotic hsp70 genes revealed by comparison with the nucleotide sequence of human hsp70. Proc. Natl. Acad. Sci. 82: 6455-6459.

Jakobsen, B.K. and H.R.B. Pelham. 1988. Constitutive binding of yeast heat-shock factor to DNA in vivo. Mol. Cell. Biol. 8: $5040-5042$.

1991. A conserved heptapeptide restrains the activity of the yeast heat shock transcription factor. EMBO /. 10: 369375.

Jurivich, D.A., L. Sistonen, R.A. Kroes, and R.I. Morimoto. 1992. Effect of sodium salicylate on the human heat shock response. Science 255: 1243-1245.

Kao, H.T. and J.R. Nevins. 1983. Transcriptional activation and subsequent control of the human heat shock gene during adenovirus infection. Mol. Cell. Biol. 3: 2058-2065.

Kost, J.L., D.F. Smith, W.P. Sullivan, W.J. Welch, and D.O. Toft. 1989. Binding of heat shock proteins to the avian progesterone receptor. Mol. Cell. Biol. 9: 3829-3838.

Larson, J.S., T.J. Schuetz, and R.E. Kingston. 1988. Activation in vitro of a sequence specific DNA binding by a human regulatory factor. Nature 335: 372-375.

Milarski, K.L. and R.I. Morimoto. 1989. Mutational analysis of the human hsp70 protein: Distinct domains for nucleolar localization and adenosine triphosphate binding. I. Cell. Biol. 109: 1947-1962.

Mitchell, P.J. and R. Tjian. 1989. Transcriptional regulation in mammalian cells by sequence specific DNA binding proteins. Science 245: 371-378.

Morimoto, R.I., A. Tissières, and C. Georgopoulos. 1990. The stress response, functions of the proteins, and perspectives. In Stress proteins in biology and medicine (ed. R.I. Morimoto, A. Tissières, and C. Georgopoulus), pp. 1-36. Cold Spring Harbor Laboratory Press, Cold Spring Harbor, New York.

Mosser, D.D., N.G. Theodorakis, and R.I. Morimoto. 1988. Coordinate changes in heat shock element binding activity and hsp70 gene transcription rates in human cells. Mol. Cell. Biol. 8: 4736-4744.

Mosser, D.D., P.T. Kotzbauer, K.D. Sarge, and R.I. Morimoto. 1990. In vitro activation of heat shock transcription factor DNA-binding by calcium and biochemical conditions that affect protein conformation. Proc. Natl. Acad. Sci. 87: 37483752 . 
Nakabeppu, Y. and D. Nathans. 1991. A naturally occuring truncated form of FosB that inhibits fos/jun transcriptional activity. Cell 64: 751-759.

Pallas, D.C., W. Morgan, and T.M. Roberts. 1989. The cellular proteins which can associate specifically with polyomavirus middle-T antigen in human 293 cells include the major human 70-kilodalton heat shock proteins. I. Virol. 63: 45334539.

Palleros, D.R., W.J. Welch, and A.L. Fink. 1991. Interaction of hsp70 with unfolded proteins: Effects of temperature and nucleotides on the kinetics of binding. Proc. Natl. Acad. Sci. 88: 5719-5723.

Parsell, D.A. and R.T. Sauer. 1989. Induction of a heat shocklike response by unfolded protein in Escherichia coli: Dependence on protein level not protein degradation. Genes \& Dev. 3: 1226-1232.

Pelham, H.R.B. 1982. A regulatory upstream promoter element in the Drosophila hsp70 heat-shock gene. Cell 30: 517-528.

. 1986. Speculations on the functions of the major heat shock and glucose regulated proteins. Cell 46: 959-961.

- 1990. Functions of the hsp70 protein family: An overview. In Stress proteins in biology and medicine (ed. R.I. Morimoto, A. Tissières, and C. Georgopoulus|, pp. 287-299. Cold Spring Harbor Laboratory Press, Cold Spring Harbor, New York.

Picard, D., B. Khusheed, M.J. Garabedian, M.G. Fortin, S. Lindquist, and K.R. Yamamoto. 1990. Reduced levels of hsp90 compromise steroid receptor action in vivo. Nature 348: $166-168$.

Pinhasi-Kimhi, O., D. Michalovitz, A. Ben-Zeev, and M. Oren. 1986. Specific interaction between the p53 cellular tumor antigen and major heat shock proteins. Nature 320: 182185.

Rabindran, S.K., G. Giorgi, J. Clos, and C. Wu. 1991. Molecular cloning and expression of a human heat shock factor, HSF1. Proc. Nat1. Acad. Sci. 88: 6906-6910.

Sanchez, E.R., D.O. Toft, M.J. Schlesinger, and W.B. Pratt. 1985. Evidence that the $90 \mathrm{kDa}$ phosphoprotein associated with the untransformed $\mathrm{L}$-cell glucocorticoid receptor is a murine heat shock protein. J. Biol. Chem. 260: 12358-12403.

Sarge, K.D., V. Zimarino, K. Holm, C. Wu, and R.I. Morimoto. 1991. Cloning and characterization of two mouse heat shock factors with distinct inducible and constitutive DNA-binding ability. Genes \& Dev. 5: 1902-1911.

Sawai, E.T. and J.S. Butel. 1989. Association of a cellular heat shock protein with simian virus 40 large $\mathrm{T}$ antigen in transformed cells. I. Virol. 63: 3961-3973.

Scharf, K.D., S. Rose, W. Zott, F. Schoff, and L. Nover. 1990. Three tomato genes code for heat stress transcription factors with a remarkable degree of homology to the DNA-binding domain of the yeast HSF. EMBO I. 9: 4495-4501.

Schuetz, T.J., G.J. Gallo, L. Sheldon., P. Tempst, and R.E. Kingston. 1991. Isolation of a cDNA for HSF2: Evidence for two heat shock factor genes in humans. Proc. Natl. Acad. Sci. 88: 6910-6915.

Smith, D.B. and K.A. Johnson. 1988. Single-step purification of polypeptides expressed in Escherichia coli as fusions with glutathione S-transferase. Gene 67: 31-40.

Solomon, J.M., J.M. Rossi, K. Golic, T. McGarry, and S. Lindquist. 1991. Changes in hsp70 alter thermotolerance and heat-shock regulation in Drosophila. New Biol. 3: 11061120.

Sorger, P.K. 1991. Heat shock factor and heat shock response. Cell 65: 363-366.

Sorger, P.K. and H.R.B. Pelham. 1987. Purification and characterization of a heat-shock element binding protein from yeast. $E M B O$ I. 6: 3035-3041.

Sorger, P.K. and H.C.M. Nelson 1989. Trimerization of a yeast transcriptional activator via coiled-coil motif. Cell 59: 807813.

Sorger, P.K., M.J. Lewis, and M.H.B. Pelham. 1987. Heat shock factor is regulated differently in yeast and HeLa cells. Nature 329: 81-84.

Straus, D.B., W.A. Walter, and C.A. Gross. 1987. The heat shock response of $\mathrm{E}$. coli is regulated by changes in the concentration of sigma 32. Nature 329: 348-351.

. 1989. The activity of $\sigma^{32}$ is reduced under conditions of excess heat shock protein production in Escherichia coli. Genes \& Dev. 3: 2003-2010.

- 1990. DnaK, dnaJ, and grpE heat shock proteins negatively regulate heat shock gene expression by controlling the synthesis and stability of $\sigma^{32}$. Genes \& Dev. 4: 2202-2209.

Studier, F.W., A.H. Rosenberg, J.J. Dunn, and J.W. Dubendorff. 1990. Use of T7 RNA polymerase to direct expression of cloned genes. Methods Enzymol. 185: 60-89.

Tilly, K., N. McKittrick, M. Zylicz, and C. Georgopoulos. 1983. The dnaK protein modulates the heat shock response of Escherichia coli. Cell 34: 641-646.

Tilly, K., J. Spence, and C. Georgopoulos. 1989. Modulation of stability of the Escherichia coli heat shock regulatory factor sigma 32. J. Bacteriol. 171: 1585-1589.

Treacy, M.N., X. He, and M.G. Rosenfeld. 1991. I-POU: A POUdomain protein that inhibits neuron specific gene activation. Nature 350: $577-584$.

Urban, M.B. and P.A. Baeuerle. 1990. The $65-\mathrm{kD}$ subunit of NF- $\mathrm{KB}$ is a receptor for $\mathrm{I}_{\kappa} \mathrm{B}$ and a modulator of DNA-binding specificity. Genes \& Dev. 4: 1974-1984.

Walter, G., A. Carbone, and W.J. Welch. 1987. Medium tumor antigen of polyomavirus transformation defective mutant NG59 is associated with 73-kilodalton heat shock protein. J. Virol. 61: 405-410.

Welch, W.J. and J.R. Feramisco. 1985. Rapid purification of mammalian 70,000 dalton stress protein: Affinity of proteins for nucleotides. Mol. Cell. Biol. 5: 1229-1236.

Welch, W.J. and L.A. Mizzen. 1988. Characterization of the thermotolerant cell. II. Effects on the intracellular distribution of heat shock protein 70 , intermediate filaments and small nuclear ribonuclear complexes. J. Cell. Biol. 106: $1117-1130$.

Westwood, J.T., J. Clos, and C. Wu. 1991. Stress induced oligomerization and chromosomal relocalization of heat-shock factor. Nature 353: 822-827.

Wickner, S., J. Hoskins, and K. McKenney. 1991. Monomerization of RepA dimers by heat shock proteins activates binding to DNA replication origin. Proc. Natl. Acad. Sci. 88: 79037907.

Wiederrecht, G., D.J. Shuey, W.A. Kibbe, and C. Parker. 1987. The Saccharomyces and Drosophila heat shock transcription factors are identical in size and DNA binding properties. Cell 48: $507-515$

Wiederrecht, G., D. Seto, and C.S. Parker. 1988. Isolation of the gene encoding the $S$. cerevisiae heat shock transcription factor. Cell 54: 841-853.

Williams, G.T., T.K. McClanahan, and R.I. Morimoto. 1989. Ela transactivation of the human HSP70 promoter is mediated through the basal transcriptional complex. Mol. Cell. Biol. 9: 2574-2587.

Wu, B., H.C. Hurst, N.C. Jones and R.I. Morimoto. 1986. The E1A 13 S product of adenovirus 5 activates transcription of the cellular human hsp70 gene. Mol. Cell. Biol. 6: 2994 2999.

Wu, C., V. Zimarino, B. Tsai, B. Walker, and S. Wilson. 1990. 


\section{Abravaya et al.}

Transcriptional regulation of heat shock genes. In Stress proteins in biology and medicine (ed. R.I. Morimoto, G. Tissières, and C. Georgopoulus), pp. 429-442. Cold Spring Harbor Laboratory Press, Cold Spring Harbor, New York.

Xiao, H. and J.T. Lis. 1988. Germline transformation used to define key features of the heat shock response element. Science 239: 1139-1142.

Zylicz, M., J.H. LeBowitz, R. McMacken, and C. Georgopoulos. 1983. The dnaK protein of Escherichia coli possesses an ATPase and autophosphorylating activity and is essential in an in vitro DNA replication system. Proc. Nat1. Acad. Sci. 80: $6431-6435$. 


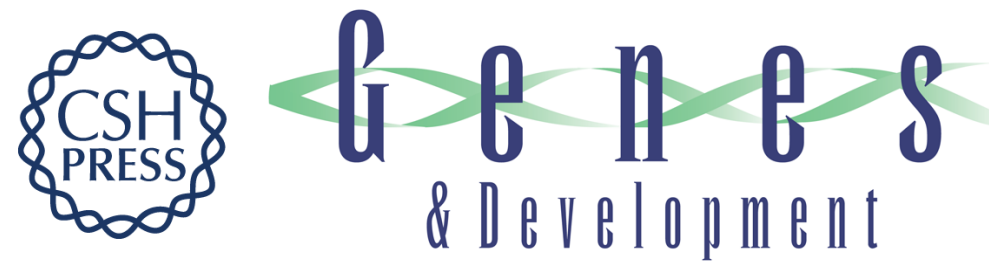

\section{The human heat shock protein hsp70 interacts with HSF, the transcription factor that regulates heat shock gene expression.}

K Abravaya, M P Myers, S P Murphy, et al.

Genes Dev. 1992, 6:

Access the most recent version at doi:10.1101/gad.6.7.1153

References This article cites 74 articles, 35 of which can be accessed free at:

http://genesdev.cshlp.org/content/6/7/1153.full.html\#ref-list-1

License

Email Alerting

Service

Receive free email alerts when new articles cite this article - sign up in the box at the top right corner of the article or click here.

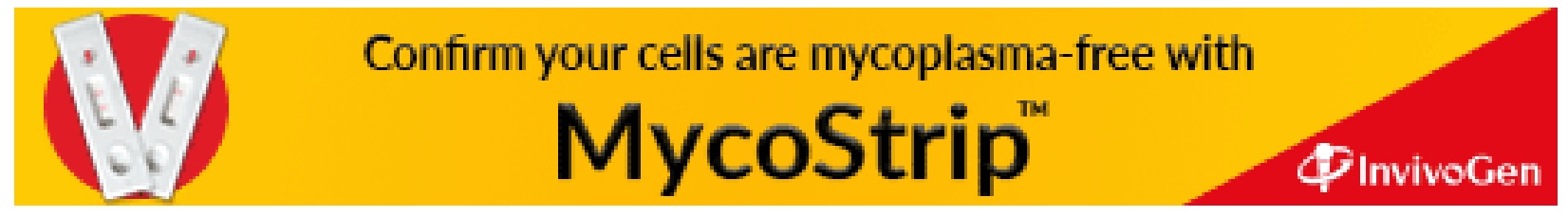

